\title{
PENGEMBANGAN E-MODUL FISIKA BERBASIS MULTIREPRESENTASI PADA MATERI GERAK LURUS
}

\author{
Bemie Eka Saputra ${ }^{1}$, Haerul Pathoni ${ }^{2}$, Dwi Agus Kurniawan ${ }^{3}$ \\ 1,2,3Program Studi Pendidikan Fisika FKIP Universitas Jambi, Jambi, Indonesia \\ Corresponding author email: bemie.saputra@email.com
}

\section{Info Artikel}

Diterima:

10 Maret 2020

Disetujui:

19 Mei 2020

Dipublikasikan:

30 Juni 2020

\begin{abstract}
Abstrak:
Tujuan pengembangan ini ialah untuk mengetahui cara mengembangankan modul elektronik 3D pageflipp profesional materi gerak lurus berbasis multirepresentasi. Jenis penelitian ini adalah penelitian pengembangan research \& development $(\mathrm{R} \& \mathrm{D})$ dengan menggunakan model ADDIE. Subjek pada penelitian ini adalah siswa SMA Kelas X di SMA N 11 Muaro Jambi. Pada penelitian pengembangan ini angket yang digunakan adalah angket tertutup, yang mana respon hanya diminta untuk memilih jawaban yang telah disediakan pada angket. Pada penelitian pengembangan ini angket yang digunakan ada dua yaitu angket untuk ahli materi (konten) dan ahli media angket persepsi untuk siswa. Analisis data kualitatif dilakukan terhadap data yang dikumpulkan berdasarkan saran dan komentar dari validator. Data kuantitatif diperoleh dari hasil penyebaran angket kepada siswa, dengan beberapa alternatif pilihan jawaban sesuai skala likert. Hasil kelayakan dari validator ahli materi sebesar $86,67 \%$ dengan kategori sangat baik. Hasil kelayakan dari validator ahli media sebesar $87 \%$ dengan kategori sangat baik. Hasil persepsi peserta didik terhadap modul elektronik 3D pageflipp profesional berbasis multirepresentasi menunjukkan sebanyak 16 orang siswa merespon sangat baik dan sebanyak 14 orang siswa merespon baik.
\end{abstract}

Kata kunci: E-modul, multirepresentasi, gerak lurus

\begin{abstract}
:
The purpose of this development is to find out how to develop of the $3 D$ electronic module pageflipp professional on straight motion material based on multiple repesentations. This type of research is research and development $(R \& D)$ research development using the ADDIE model. The subjects in this study were high school students in Class X at Muaro Jambi 11 High School. In this research development the questionnaire used was a closed questionnaire, in which the response was only asked to select the answers provided in the questionnaire. In this research development there are two questionnaires used, namely questionnaire for material experts (content), and perception questionnaire media for students. Qualitative data analysis is performed on the data collected, based on suggestions and comments from the validator. Quantitative data were obtained from the results of the distribution of questionnaires to students, with several alternative answer choices according to the Likert scale. The result of feasibility of the material expert validator were $86,67 \%$ with the very good category. The results of the feasibility of the media expert validator are $87 \%$ with the very good category. The results of students perceptions of the professional 3D pageflipp electronic module based on multirepresentation materials showed that 16 students responded very well and 14 students responded well.
\end{abstract}

Keywords: E-module, multirepresentation,linier motion 


\section{Pendahuluan}

Fisika merupakan suatu cabang ilmu pengetahuan sains. Fisika mempelajari tentang sesuatu yang konkret dan dapat dibuktikan secara matematis. Pada dasar-nya pembelajaran fisika perlu disesuaikan dengan cara fisikawanterdahulu dalam memperoleh pengetahuan. Oleh karenaitu, dalam pembelajaranfisika harus diarahkan untuk mencari tahu dan berbuat sehingga dapat membantu mahasiswa untuk memperoleh penguasaan konsep yang lebih mendalam (Kurniawati \& Nita, 2018). Dari keterangan beberapa siswa, mereka berpendapat bahwa fisika merupakan mata pelajaran yang sulit karena banyaknya rumus dan sulitnya memahami konsep fisika, selain itu materi fisika yang dipelajari juga banyak. Sehingga hasil belajar yang dihasilkan masih rendah (Kamilah, 2015).

Berdasarkan studi awal pada peserta didik kelas X di SMAN 11 Muaro Jambi yang telah dilakukan oleh peneliti, hasilnya menunjukkan bahwa profil kecerdasan yang dimiliki oleh peserta didik sangat beragam. Hal ini diperkuat dengan hasil dari 20 peserta didik yang mengikuti tes kecerdasan jamak, $10 \%$ peserta didik memiliki kecerdasan musik yang dominan, $10 \%$ peserta didik memiliki kecerdasan intrapersonal yang dominan, dan 25\% peserta didik memiliki kecerdasan dominan interpersonal, sedangkan peserta didik lainnya memiliki kecerdasan dominan matematikalogika hanya 5\%. Kecerdasan dominan yang dimiliki peserta didik adlaah Representasi visual sebesar $30 \%$. Selain itu kendala yang dialamai oleh peserta didik adalah keterbatasan bahan ajar materi Gerak Lurus yang kaya dengan ragam representasi (multiple representasi) dalam bentuk cetak, maupun dalam bentuk elektronik.Sehingga bahan ajar Gerak Lurus sangat dibutuhkan untuk proses belajar mengajar di kelas.

Persoalan sekarang adalah bagaimana menemukan cara yang terbaik untuk menyampaikan materi yang diajarkan sehingga siswa dapat memahami dan mengingat lebih lama materi yang diajar tersebut serta kemampuan pemecahan masalah Fisika siswa yang tinggi. Sebagai guru yang baik dan bijaksana harus mampu mengubah kesulitan pembelajaraan tersebut menjadi pembelalajaran aktif, kritis, efektif, dan menyenangkan (Mustofa \& Rusdiana, 2016).

Representasi adalah kemampuan siswa mengkomunikasikan ide/gagasan matematika yang dipelajari dengan cara tertentu. Ragam representasi yang sering digunakan dalam mengkomunikasikan ide-ide matematis antara lain: diagram (gambar) atau sajian benda konkrit, tabel chart, pernyataan matematika, teks tertulis, ataupun kombinasi dari semuanya (Hutagaol, 2013). Tampaknya multirepresentasi dapat di-jadikan sebagai pendekatan dalam pembelaja-ran Fisika. Tampilan berbagai representasi da-lam penanaman suatu konsep diprediksi akan dapat lebih membantu peserta didik dapat me-mahami konsep yang dipelajari. Hal ini terkait dengan setiap peserta didik (siswa atau mahasiswa) memiliki kemampuan sfesifi $\mathrm{k}$ yang lebih menonjol dibanding kemampuan lainnya. Ada peserta didik yang lebih menonjol kemampuan verbalnya dibanding kemampuan spasial dan kuantitatifnya, tetapi ada juga yang sebaliknya (Suhandi \& Wibowo. 2012). Sebuah representasi dapat berupa kombinasi dari sesuatu yang tertulis di atas kertas, sesuatu yang eksis dalam bentuk obyek fisik dan susunan ide-ide yang terkontruksi di dalam pikiran seseorang (Nitz et al., 2014). Pengertian yang paling umum, multirepresentasi adalah suatu konfigurasi yang dapat menggambarkan sesuatu yang lain dalam beberapa cara (Godino et al., 2010).

Dalam pembelajaran, fisika menuntut siswa untuk menguasai representasi-representasi berbeda (percobaan, grafik, konseptual, rumus, gambar, diagram) (Widianingtiyas et al., 2015). Memandang keterampilan merepresentasikan konsep-konsep merupakan kompetensi ilmiah yang harus dikuasai oleh guru dengan baik. Kompetensi ilmiah ini meliputi keterampilan dalam merepresentasikan suatu informasi dengan beragamcara (Ainsworth et al., 2011). Pemahaman multi representasi siswa dalam memahami fisika perlu dimunculkan oleh pendidik ke dalam berbagai bentuk penyajian informasi sehingga siswa mampu memahami suatu masalah yang abstrak menjadi konkrit dalam semua ranah tinjauan (Hasbullah et al., 2019).

Faktor pendukung dalam proses bel-ajar mengajar di antaranya adalah media dan bahan ajar. Bahan ajar atau sering dise-but sebagai materi pelajaran merupakan ba-gian terpenting dalam proses pembelajaran, materi pelajaran merupakan inti dari kegiat-an pembelajaran (Herawati \& Muhtadi, 
2018). Menurut National Center for Vocational Education Research Ltd/National Center for Competency Based Training, bahan ajar adalah segala bentuk bahan yang digunakan untuk membantu guru/ instruktur dalam melaksanakan kegiatan belajar mengajar di kelas (Nugraha \& Binadja. 2013). Keberadaan modul saat ini masih masih bersifat verbal atau tekstual sehingga peserta didik masih merasa kurang tertarik untuk membacanya (Yusro \& Sasono, 2016). Modul elektronik merupakan alat atau sarana pembelajaran yang berisi materi, metode, batasan-batasan dan cara mengevaluasi yang dirancang secara sistematis dan menarik untuk mencapai kompetensi yang diharapkan (Sari.2013).

Modul elektronik merupakan alat atau sarana pembelajaran yang berisi materi, metode, batasan-batasan dan cara mengevaluasi yang dirancang secara sistematis danmenarikuntuk mencapai kompetensi yang diharapkan. Modul elektronik adalah bagian dari electronic based e-learning yang pembelajarannya memanfaatkan teknologi informasi dan komunikasi, terutama perangkat berupa elektronik. melalui modul suatu pembelajaran diharapkan mampu membawa peserta didik pada kompetensi dasar yang diharapkan (Winaya et al., 2016).

Berdasarkan hasil angket terbuka, secara umum peserta didik menyukai jika belajar fisika menggunakan bahan ajar/modul interaktif. Bahan ajar ini diharapkan bisa membantu peserta didik untuk memahami konsep fisika, dan membuat belajar fisika menjadi lebih menyenangkan. Hal ini memberikan dorongan bagi peneliti untuk melakukan penelitian pengembangan bahan ajar fisika SMA kelas X materi Gerak Lurus.

\section{Metode Penelitian}

Metode penelitian yang peneliti gunakan adalah dengan model yaitu Analisis (Analyzing), Desain (Design), Pengembangan (Development), Implementasi (Implementation), dan Evaluasi (Evaluate) atau lebih sering disingkat dengan model ADDIE. Model ini memiliki beberapa tahapan yang sesuai dengan namanya yaitu (1) analisis, (2) Desain, (3) pengembangan, (4) Implementasi dan diakhiri dengan tahap (5) evaluasi, namun model ADDIE memiliki fokus atau penekanan pada iterasi dan refleksi. Sehingga perbaikan secara terus menerus dapat dilakukan yang berfokus dari umpan balik(Harjanta \& Herlambang, 2018)ADDIE merupakan singkatan dari analysis (analisis), design (desain), development (pengembangan), implementation (implementasi), dan evaluate (evaluasi). Model ADDIE dikenal dengan model melingkar. Model ini mengembangkan desain pembelajaran.

Dengan subjek uji coba pada penelitian ini adalah siswa SMA Kelas X di SMA N 11 Muaro Jambi. Siswa yang dijadikan subjek pada penelitian ini adalah siswa perminatan matematika dan ilmu alam (MIA).

Prosedur pengembangan bahan ajar berupa modul elektronik pembelajaran Fisika materi Gerak Lurus ini hanya dibatasi pada tahap development (pengembangan) dengan evaluasi 1 tahap.

1. Tahap analysis langkah-langkah yang harus dilakukan pada tahap ini adalah memvalidasi permasalahan, menentukan tujuan, menganalisis pembelajar, melihat sumber daya yang tersedia, dan menyusun rencanakerja.

2. Tahap desain merupakan tahapan perancangan dan pembuatan produk. Langkah yang harus dilaksanakan pada tahap ini adalah mengumpulkan dan membuat produk yang telah dirancang, menyusun tujuan pelaksanaan atau pengembangan, dan menyusun strategi pengujian.

3. Pada tahap pengembangan ini akan dilakukan produksi modul elektronik dan melakukan validasi produk. Proses pengembangan (development) modul elektronik mengikuti tahap awal mulaidarianalisis, perencanaan, sampai dengan tahap pengembangan.

4. Tahap implementasi (implementation) merupakan tahapan sesungguhnya untuk menerapkan mengimplementasikan produk berupa modul elektronik yang telah dikembangkan.

5. Tahap evaluasi dilakukan pada setiap tahapan mulai dari analisis, desain dan pengembangan.

\section{Hasil Penelitian dan Pembahasan}

Penelitian merupakan penelitian pengembangan research \& development (R\&D) menggunakan model ADDIE yang terdiri dari tahapan analysis (analisis), design (desain), Pengembangan E-Modul Fisika.... (Bemie Eka Saputra, dkk) hal:39-44 
development (pengembangan), implementation (implementasi), dan evaluate (evaluasi).

1. Analisis, analisis siswa diperoleh berdasarkan hasil angket yang diberikan kepada siswa. Berdasarkan hasil analsis angket diperoleh bahwa siswa kurang minat dalam mata pelajaran fisika karena media yang digunakan hanya buku pelajaran. Siswa kurang focus dalam pembelajaran karena proses pembelajaran tidak melibatkan peran aktif siswa. Hasil respon siswa dianalisis menggunakan persentasi skor penilaian, uji validitas dan uji reliabilitas untuk mengukur kriteria penilaian, keabsahan dan kekonsistenan media yang dikembangkan.

2. Desain, Tahap ini terdiri daritahap perancangan dan pembuatan desainproduk. Hasil dari tahap perancangan dijadikan acuan pembuatan produk pada tahappengembangan.

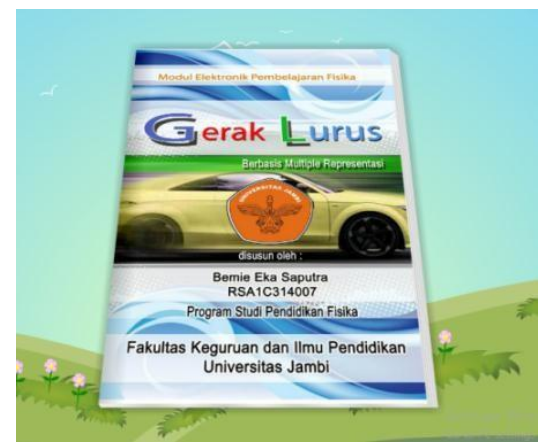

Gambar 1. Desain cover bagian depan modul.

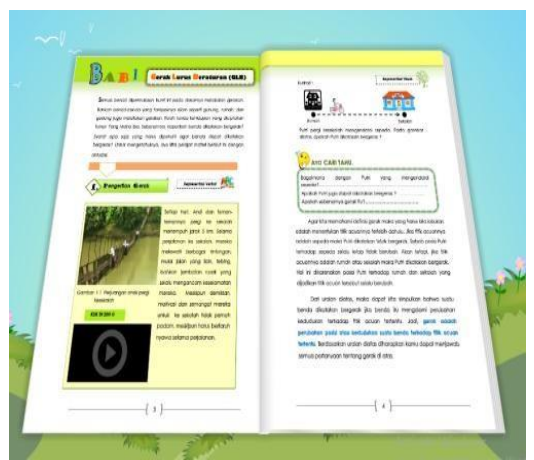

Gambar 2. Desain penjelasan materi

3. Pengembanga, Pengembangan dilakukan untuk merealisasikan hasil rancangan desain produk. Pada tahap ini dihasilkan media berupa bahan ajar elektronik dalam bentuk 3D Pageflippp Professional. Media divalidasi oleh dosen ahli materi dan media. Ahli materi menilai media dari segi konten dan bahasa dari media yang digunakan berdasarkan kebenaran konsep fisika yang digunakan khususnya pada materi Gerak Lurus. Persentasi hasil rata-rata penilaian ahli materi sebesar $86,67 \%$. Hasil ini menunjukkan bahwa materi pada media bahan ajar elektronik yang dikembangkan berada pada kategori sangat baik (Ghofur. 2015). Persentasi hasil rata-rata penilaian ahli media sebesar $87 \%$.. Hasil ini menunjukkan bahwa media bahan ajar elektronik yang dikembangkan berada pada kategori sangat baik (Ghofur. 2015). Penilaian ahli materi dan media dijadikan bahan revisi dan selanjutnya dilakukan implementasi yaitu penerapan media dalam proses pembelajaran.

4. Implementasi, Berdasarkan hasil tabel respon siswa jumlah siswa yang merespon media dengan kriteria sangat baik sebanyak 16 orang siswa dan siswa yang merespon media dengan kriteria baik sebanyak 14 orang siswa. Hasil ini menunjukkan bahwa siswa 
memberikan respon yang baik terhadap penerapan media bahan ajar elektronik 3D Pageflippp professional. Selama pembelajaran siswa siswa antusias menggunakan media dan beberapa siswa mengajukan pertanyaan terkait materi dan penggunaan media bahan ajar.

Tabel 1. Hasil reliabilitas menggunakan program SPSS

\begin{tabular}{ccc}
\hline \multicolumn{3}{c}{ ReliabilityStatistics } \\
\hline \multicolumn{3}{c}{ Cronbach's } \\
Alpha Based \\
on \\
Cronbach & Standardized \\
's Alpha & Items & N of Items \\
0.682 & 0.725 & 27 \\
\hline
\end{tabular}

Hasil validitas menunjukkan 21 butir respon siswa termasuk kategori valid sedangkan 6 butir termasuk kategori tidak valid. Setelah validitas maka akan diuji reliabilitas. Hasil reliabilitas pada Tabel 2. sebesar 0,68. Hasil ini menunjukkan bahwa modul elektronik 3D pageflippp profesional materi Gerak Lurus berbasis representasi visual yang dikembangkan reliable sehingga modul yang dikembangkan bisa digunakan dalam pembelajaran di kelas.

5. Evaluasi, yakni dilakukan evaluasi pada setiap tahap pengembangan.

\section{Simpulan}

Pengembangan media bahan ajar elektronik 3D Pageflipp yang berbasis represemtasi visual dikembangkan menggunakan model ADDIE layak digunakan dalam pembelajaran dengan nilai validitas menunjukkan 21butir. Persepsi peserta didik terhadap modul elektronik 3D pageflipp profesional Fisika SMA Kelas X materi GLB dan GLBB berbasis multirepresentasi di SMA N 11 Muaro Jambi menunjukkan hasil respon siswa menunjukkan sebanyak 16 orang siswa merespon sangat baik penggunaan media sedangkan sebanyak 14 orang siswa merespon baik media pembelajaran yang digunakan.

\section{Referensi}

Ainsworth, S., Prain, V., \& Tytler, R. (2011). Drawing to learn in science. In Science. https://doi.org/10.1126/science. 1204153

Ghofur, A. (2015). Pengembangan e-book berbasis flash kvisoft flipbook pada materi kinematika gerak lurus sebagai sarana belajar siswa SMA kelas X. Inovasi Pendidikan Fisika, 4(2).

Godino, J., Font, V., \& del Professorat, F. (2010). The theory of representations as viewed from the onto-semiotic approach to mathematics education. Mediterranean Journal for Research in Mathematics Education, 9(1).

Harjanta, A. T. J., \& Herlambang, B. A. (2018). Rancang Bangun Game Edukasi Pemilihan Gubernur Jateng Berbasis Android Dengan Model ADDIE. Jurnal Transformatika, 16(1). https://doi.org/10.26623/transformatika.v16il.894

Hasbullah, H., Halim, A., \& Yusrizal, Y. (2019). Penerapan Pendekatan Multi Representasi Terhadap Pemahaman Konsep Gerak Lurus. Jurnal IPA \& Pembelajaran IPA, 2(2). https://doi.org/10.24815/jipi.v2i2.11621

Herawati, N. S., \& Muhtadi, A. (2018). Pengembangan modul elektronik (e-modul) interaktif pada mata pelajaran Kimia kelas XI SMA. Jurnal Inovasi Teknologi Pendidikan, 5(2). https://doi.org/10.21831/jitp.v5i2.15424

Hutagaol, K. (2013). Pembelajaran Kontekstual Untuk Meningkatkan Kemampuan Representasi Matematis Siswa Sekolah Menengah Pertama. Infinity Journal, 2(1). 
https://doi.org/10.22460/infinity.v2i1.27

Kamilah, D. (2015). Upaya Peningkatan Aktivitas dan Hasil Belajar Kinematika Gerak Lurus Melalui Strategi Siklus Ace Kelas XB SMA Negeri 2 Simpang Hilir. Jurnal Visi Ilmu Pendidikan, 7(3). https://doi.org/10.26418/jvip.v7i3.17201

Kurniawati, I. D., \& Nita, S.-. (2018). Media Pembelajaran Berbasis Multimedia Interaktif Untuk Meningkatkan Pemahaman Konsep Mahasiswa. DoubleClick: Journal of Computer and Information Technology, 1(2). https://doi.org/10.25273/doubleclick.v1i2.1540

Ma'rifa, M., Kamaluddin, H., \& Fihrin, H. (2016). Analisis Pemahaman Konsep Gerak Lurus pada Siswa SMA Negeri di Kota Palu. JPFT (Jurnal Pendidikan Fisika Tadulako Online), 4(3). https://doi.org/10.22487/j25805924.2016.v4.i3.6060

Mustofa, M. H., \& Rusdiana, D. (2016). Profil Kemampuan Pemecahan Masalah Siswa pada Pembelajaran Gerak Lurus. Jurnal Penelitian \& Pengembangan Pendidikan Fisika, 2(2). https://doi.org/10.21009/1.02203

Nitz, S., Prechtl, H., \& Nerdel, C. (2014). Survey of classroom use of representations: development, field test and multilevel analysis. Learning Environments Research, 17(3). https://doi.org/10.1007/s10984-014-9166-x

Nugraha, D. A., \& Binadja, A. (2013). Pengembangan bahan ajar reaksi redoks bervisi SETS, berorientasi konstruktivistik. Journal of Innovative Science Education, 2(1).

Sari, D. P. (2013). Pengembangan Modul Elektronik Berbasis POEI (Prediksi, Observasi, Ekperimen, Interpretasi) pada Mata Kuliah Fisika Teknik. Jurnal Penelitian Pendidikan, 18(3), 276-283.

Suhandi, A., \& Wibowo, F. C. (2012). Pendekatan multirepresentasi dalam pembelajaran usaha-energi dan dampak terhadap pemahaman konsep mahasiswa. Jurnal Pendidikan Fisika Indonesia, 8(1).

Widianingtiyas, L., Siswoyo, S., \& Bakri, F. (2015). Pengaruh Pendekatan Multi Representasi dalam Pembelajaran Fisika Terhadap Kemampuan Kognitif Siswa SMA. Jurnal Penelitian \& Pengembangan Pendidikan Fisika, 1(1). https://doi.org/10.21009/1.01105

Winaya, I. K. A., Darmawiguna, I. G. M., \& Sindu, I. G. P. (2016). Pengembangan E-Modul Berbasis Project Based Learning Pada Mata Pelajaran Pemrograman Web Kelas X Di Smk Negeri 3 Singaraja. Jurnal Pendidikan Teknologi Dan Kejuruan, 13(2). https://doi.org/10.23887/jptk.v13i2.8527

Yusro, A. C., \& Sasono, M. (2016). Penggunaan Modul Ilustratif Berbasis Inkuiri Terbimbing Pokok Bahasan Kinematika Gerak Lurus Untuk Meningkatkan Hasil Belajar Dan Kemandirian Siswa Kelas Vii Smpn 14 Madiun. Jurnal Pendidikan Fisika Dan Keilmuan (JPFK), 2(1). https://doi.org/10.25273/jpfk.v2i1.22 